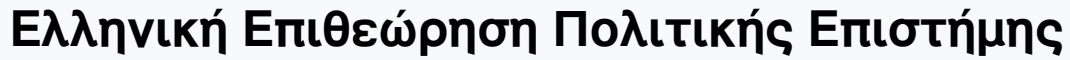

Tó 39 (2012)

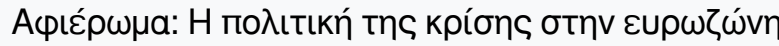

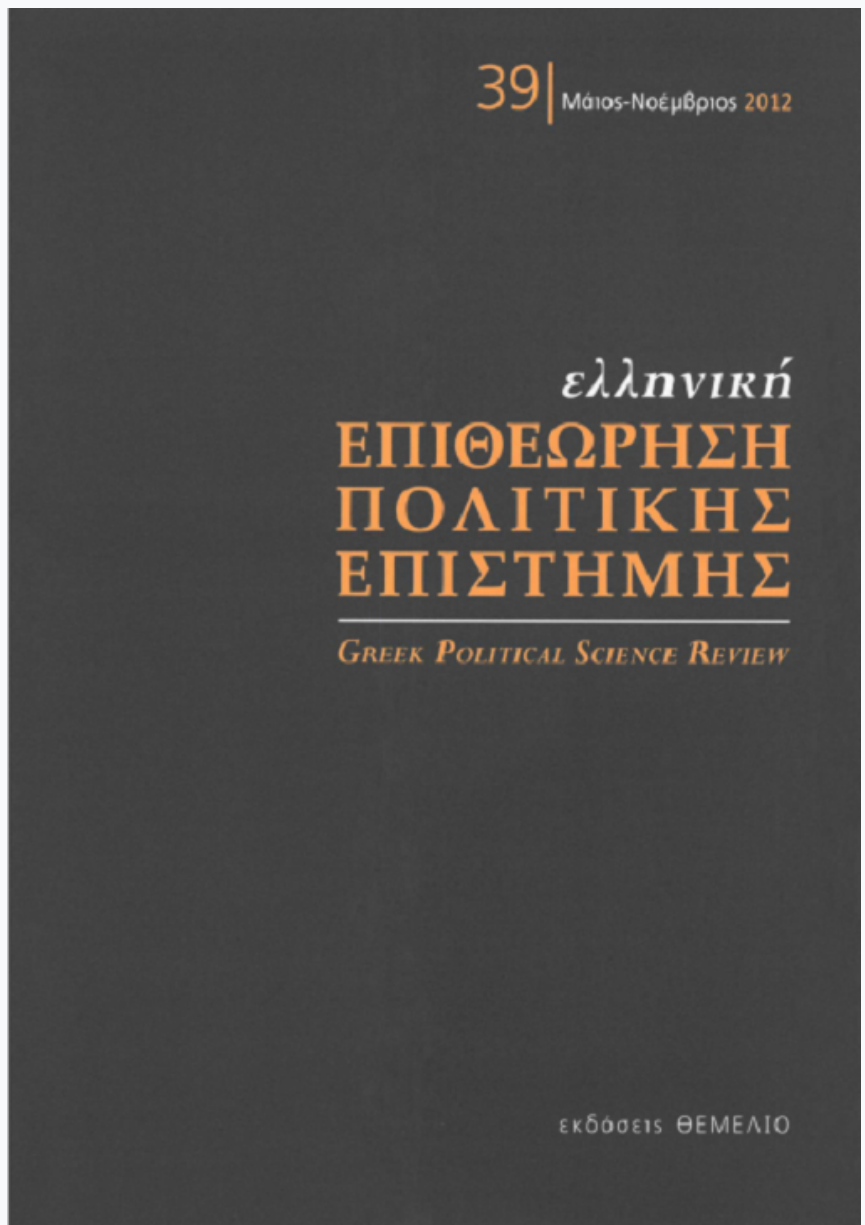

\section{Between collateral damage and "iron law"}

Janis A. Emmanouilidis

doi: $10.12681 / \mathrm{hpsa} .14548$

\section{Copyright @ 2017, Janis A. Emmanouilidis}

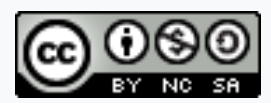

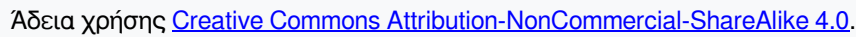

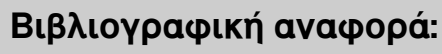

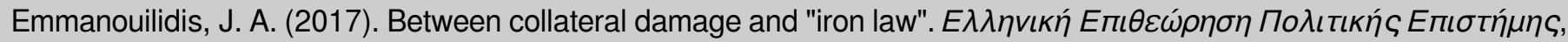
39, 106-126. https://doi.org/10.12681/hpsa.14548 


\title{
Between COllateral Damage AND "IRON LAW"
}

\author{
Janis A. Emmanouilidis*
}

\begin{abstract}
The article argues that the euro crisis has put European integration to a major test-more profound and more serious than ever before. Beyond the more immediate financial and economic effects, the crisis has inflicted collateral damage: unintended and unexpected consequences at both the national and European level, which could jeopardise not only the EU's ability to manage (and overcome) the current crisis but also its ability toaddress future internal and external challenges. The article examines four of these consequences: (1) the growing distrust between national capitals and national societies; (2) the widening "democratic gap" at both EU and national level; (3) the new balance of power and the "new German question"; and, finally, (4) the acceleration of Europe's global political and economic marginalisation.
\end{abstract}

The sovereign debt crisis has put European integration to a major test -more profound and more serious than ever before. The crisis has cast doubt on the fundamentals of the European project The unthinkable became thinkable: the exit of a country from the Eurozone, the end of the euro area -at least as we know it-, and even a disintegration of the European Union (EU) are no longer taboo. The final outcome of the euro debt crisis is by no means certain. But even if the immediate crisis is managed and eventually overcome, it is questionable whether the "iron law" of European integration history -i.e. that the European project always emerges stronger out of crises- will prove itself again.

Will the EU be able to "exploit" the current crisis and emerge stronger than before? In an attempt to answer this question, it is worth examining the state of the crisis and the main "collateral damage" caused by the crisis at both the European and national level.

* Janis A. Emmanouilidis is Senior Policy Analyst and Head of Programme at the European Policy Centre (EPC) in Brussels. 


\section{STATE OF THE CRISIS}

When the euro debt crisis broke out in Greece in late 2009/early 2010, it became clear that the EU was insufficiently equipped for bad weather conditions, as the Economic and Monetary Union (EMU) lacked the appropriate institutional structures, procedures, rules, and instruments to effectively face the sovereign debt crisis. ${ }^{1}$ At times, the situation seemed out of control as the Union proved unable to move ahead of the "markets" and stop the crisis spreading from Greece to other member states. By early 2011 the crisis had fully reached Ireland and Portugal, who were forced to join Greece in asking for financial assistance from its EU partners and the International Monetary Fund (IMF) in exchange for drastic austerity measures and ambitious national reform programmes. But the euro debt crisis was far from over.

After an agreement in March 2011 on key elements of a comprehensive economic governance package (including inter alia a permanent rescue mechanism -European Stability Mechanism - ESM- ${ }^{2}$ a strengthening of the Stability and Growth Pact, ${ }^{3}$ the introduction of the so-called "European Semester", 4

1. See J. Pisani-Ferry - A. Sapir, "Euro Area: Ready for the Storm" in J. Pisani-Ferry - A. Posen (eds.), The Euro at Ten: The Next Global Currency?, Brussels 2009, pp. 69-84; B. Marzinotto - J. Pisani-Ferry - A. Sapir, "Two Crises, Two Responses", Bruegel Policy Brief, 2010/01, March 2010; A. Sapir, "Crisis and the governance of the Euro Area" in L. Tsoukalis J.A. Emmanouilidis (eds.), The Delphic Oracle on Europe-Is there a Future for the European Union?, Oxford University Press, Oxford 2011, pp. 91-105.

2. The European Stability Mechanism (ESM) is a permanent last-resort rescue mechanism set up outside the EU on the basis of a treaty among Eurozone members and able to issue tripleA bonds to provide, together with the International Monetary Fund (IMF), assistance to euro countries in difficulty, on the basis of strict conditionality. See also J.A. Emmanouilidis, "A quantum leap in economic governance-but questions remain", EPC Post-summit Analysis, Brussels, March 2011, pp. 4-8.

3. The strengthened Stability and Growth Pact (SGP) -putting in place a third version of the SGP- aims to enhance the surveillance of fiscal policies and to apply enforcement measures more consistently and at an earlier stage. The "SGP III" is a tighter version of the original Pact set up in 1997, which was watered down in 2005 after Paris and Berlin refused to abide by the rules. The "SGP III" includes three key innovations designed to improve fiscal discipline: a wider range of reputational and financial sanctions and measures in both the preventive and corrective arms of the SGP; a higher level of "automaticity" in the decision-making procedure; and the inclusion of the overall level public debt.

4. The European Semester was introduced in 2010 as one of the key pillars of enhanced economic governance. Drawing on the lessons of the crisis, which highlighted the extent of economic interdependence, this new instrument aims to enhance ex ante coordination of key 
and the establishment of a new system of macroeconomic surveillance), ${ }^{5}$ there was some cautious optimism that the crisis could be contained. ${ }^{6}$

But these hopes evaporated quickly and in early summer 2011 a worsening of the fiscal, economic and political situation in Greece revived fears that the crisis could further deepen and spread well beyond the euro countries already receiving financial support (Greece, Ireland and Portugal). There were fears in Europe and beyond that Greece might become a "second Lehman Brothers", i.e. that Athens would be cut off from EU-IMF loans and forced into a disorderly default provoking an uncontrolled chain reaction with enormous repercussions not only for Greece and Europe, but potentially also for the global financial system.

The crisis snowball kept growing in the second half of 2011. As the borrowing costs of Spain and Italy were reaching unbearable levels, it had become obvious to (almost) everyone that without decisive action, the unthinkable might become possible: the break-up of the Eurozone or even the disintegration of the EU.

The deterioration of the situation in Europe's periphery, the growing threat of the debt crisis affecting core countries in the Eurozone, renewed tensions in the European banking sector, and the danger of another major economic slowdown increased pressures on EU governments to take bolder actions. As a consequence, Eurozone governments seemed more eager to work out and implement a more comprehensive plan to get ahead of the crisis curve ${ }^{7}$-including a strengthening of the two main rescue mechanisms (EFSF/ESM), an

economic and fiscal priorities. Under this new system, surveillance takes place in the first half of the year before national budgets and economic reform programmes are finalised. The European Semester also integrates the additional commitments made by the 23 countries participating in the Euro Plus Pact, including all 17 euro countries and six non-euro countries which opted to join the Pact voluntarily (Bulgaria, Denmark, Latvia, Lithuania, Poland, and Romania). For more see e.g.: M. Hallerberg et al, "How effective and legitimate is the European Semester? Increasing the role of the European Parliament", Bruegel Briefing Paper, Brussels 2011.

5. The new surveillance system for macro-economic imbalances is an annual assessment of the risks of macro-economic imbalances and vulnerabilities, given that the sovereign debt crisis has proven that persistent and large imbalances and divergences in competitiveness, particularly among Eurozone countries, are a major threat to the functioning of EMU.

6. See J.A. Emmanouilidis, "A quantum leap in economic governance-but questions remain", op.cit.

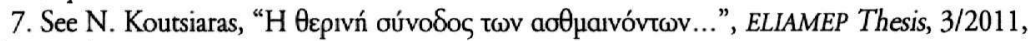
Athens, July 2011. 
orderly restructuring of Greek debt, a recapitalisation of major European banks, and a fiscal compact laid down in an intergovernmental treaty ("Treaty on Stability, Coordination and Governance in the Economic and Monetary Union"), which in the end was signed by 25 member states (not including the UK and the Czech Republic). ${ }^{8}$

In the early months of 2012 there were indications that the crisis had moved from a "hot" into a "cold(er) phase" following the bold market interventions of the ECB in December 2011 and February 2012 allowing commercial banks to borrow roughly $€ 1$ trillion in the framework of the so-called "longer-term financing operation" (LTRO). The ECB's action averted a liquidity squeeze and calmed down bond markets, as banks used "cheap" ECB loans (at around 1\% interest rate) to inter alia buy sovereign bonds, leading to a substantial reduction of borrowing costs for countries under strain such as Italy and Spain.

However, the crisis was by no means overcome, although the ECB's intervention and the appreciation of market players that central bankers in Frankfurt seemed ready to extend their crisis responses even further -if need be - had somehow increased market confidence. Yet, at the end of the day, the ECB is only able to "buy" Europeans time. It is no substitute for further efforts to counter the immediate and more fundamental causes of the sovereign debt crisis at both European and national level.

At the time of writing (May 2012), the immediate crisis situation remains highly fragile for a number of key reasons:

- First, EU institutions and Eurozone countries still have to provide clear and convincing evidence of the effectiveness of the new system of enhanced economic governance. A deterioration of public finances in key euro countries (e.g. in Spain, Italy, France or in the Netherlands) could lead to a softening of budgetary objectives, signalling to markets that Europe is (again) failing to stick to its new fiscal regime.

- Second, the economic situation in most euro countries remains under pressure, which increases the level of economic divergence within the euro area and undermines the ability and readiness of Eurozone countries to do what is required at European and national level to manage and eventually

8. See J.A. Emmanouilidis, "All roads lead to Frankfurt-the results of an enigmatic summit", EPC Post-summit Analysis, Brussels, December 2011.

9. See J.A. Emmanouilidis, "The perils of complacency-the results of an unspectacular summit", EPC Post-summit Analysis, March 2012, p. 2. 
overcome the crisis - confidence in national governments and "solidarity" between governments is close to being exhausted.

- Third, the economic, political ${ }^{10}$ and social situation in Greece remains under strain and overall uncertainty regarding the country's future in the Eurozone (i) makes it difficult to break the negative cycle of pessimism, (ii) undermines efforts to fundamentally reform the country, and (iii) casts doubt as to whether Greece will in the foreseeable future be able to push the economic "restart button" under the conditions of the current crisis recipe. ${ }^{11}$

- Fourth, it remains uncertain whether the "problem countries" in the Eurozone -including not only programme countries (Greece, Ireland and Portugal) but also other member states strongly affected by the crisis (like Italy and Spain)- will be able to continue to slash public expenditure, push through structural reforms and increase their economic competitiveness in order to trigger growth and to return and stay on a sustainable path of fiscal virtue.

Two-and-a-half years after its outbreak, the euro crisis remains highly volatile. There is no guarantee that the crisis will be overcome. Despite all efforts, the EU and its members have up till now failed to get ahead of the curve and persuade "markets" and citizens that EU institutions and member states are capable of meeting the challenges posed by the sovereign debt crisis.

\section{2. "COllateral DAMAGE" CAUSED BY THE CRISIS}

Beyond the more immediate financial and economic effects, the crisis has inflicted collateral damage: unintended and unexpected consequences of the crisis at both the national and European level. These effects of the crisis are not always immediately visible, but they could jeopardise not only the Union's ability to manage (and overcome) the debt crisis but also its ability to address future internal and external challenges.

But what collateral damage was caused by the crisis and how could it affect the future of European integration? Four major consequences of the crisis are worth examining: (1) the growing distrust between national capitals and soci-

10. See, for example, N. Malkourzis, "Griechenlands schmerzhafter politischer Wandel", Internationale Politikanalyse, Friedrich-Ebert-Stiftung, Berlin, May 2012.

11. L. Tsoukalis, "Greece in the euro area: odd man out, or precursor of things to come?" in W.R. Cline - G. Wolff (eds.), Resolving the European Debt Crisis, Special Report 21, Peterson Institute for International Economics, March 2012, pp. 30-34. 
eties; (2) the widening "democratic gap"; (3) the new balance of power and the "new German question"; and (4) global political and economic marginalisation.

\section{(i) Growing distrust between national capitals and societies}

The EU is burdened by a growing distrust among member states. The financial and economic challenges of the global crisis after the fall of Lehman Brothers in September 2008 had already provoked self-contemplation, national egoism, and even some unilateral reactions. But the effects of the euro debt crisis have been even worse as they go well beyond the realm of the economy.

The euro crisis and reactions to it have widened old cracks and opened new wounds, which will take time to heal and some scars are likely to remain. ${ }^{12}$ Old stereotypes and inappropriate historical reminiscences have reappeared. The public confrontation between Greece and Germany had been the most unpleasant experience as the media, some commentators, and individual politicians on both sides broke out of bounds. Mutual accusations reached a level unworthy of the common history and the many personal, cultural and economic ties between both countries.

But the debt crisis has not only harmed the relationship between Athens and Berlin. Mutual recriminations about a lack of solidarity carry the seeds of a new European divide. Anger over the crisis has been increasing in both weaker and stronger EU countries. On the one hand, the weakest hold that the EU and especially core countries in the Eurozone (first and foremost Germany) reacted too cautiously especially in the early phase of the crisis and that "lender countries" have imposed too many burdens on member states in trouble while asking for too much too quickly.

The strongest, on the other hand, feel overburdened and betrayed, and fear that they will have to "pay" for the self-inflicted problems in Europe's periphery and that the EU might eventually turn into a permanent "transfer union". On both sides, there is an increasing national focus and a rise of populist rhetoric profiting from growing anti-EU sentiments - a phenomenon that cannot "only" be witnessed on the extreme right or left of the political spectrum but also in some traditional centrist parties. The EU is increasingly portrayed as a problem and citizens and elites on both sides challenge the current recipes for curing the crisis.

12. See J.A. Emmanouilidis, “Europe's Dominos of Doom”, Project Syndicate, May 2010. 
Obviously, the realities of the crisis at both the national and European are much more complex. However, the different perceptions and understandings of the euro debt crisis are creating a dangerous mixture, which could lead to or foster not only social unrest and political turbulence in certain member states, but also to increasing political tensions within the Union and among EU capitals -an increasing danger as the crisis grows older.

Even if the Union, at the end of the day, should be able to contain and manage the financial and economic effects of the crisis, the national and transnational political repercussions of the crisis must be just as great a concern for the future of European integration. Rising nationalism, populism and a poisoned atmosphere among EU countries could lead to a standstill, or even challenge the accomplishments of the European project.

Major political standoffs could lead to paralysis if individual member states -either in the core or in the periphery of the EU- would obstruct a further development of the Union's incomplete politico-institutional system. The already existing legal and institutional inadequacies of the Lisbon Treaty ${ }^{13}$ and future challenges inside and/or outside the Union will at some point in time most likely require further substantial reforms of the Union's primary law. But the political ability and appetite in EU capitals and in Brussels to engage in yet another major treaty reform exercise is rather low after the painful experience with the Constitutional Treaty and the Lisbon Treaty and due to the fact that any substantial treaty reform would require the consensus of all EU governments and a successful ratification in all member states. An inability to further develop the EU's primary law in order to increase the Union's effectiveness could in the end prove to be politically and economically very costly, if the Union gets stuck in a (permanent) reform gridlock due to the opposition of individual EU governments.

\section{(ii) Democracy challenges}

Manifold challenges related to the debt crisis and the strengthening of European economic governance have posed a number of interlinked challenges for democracy at both the European and national level. Three key chal-

13. See, for example, J.-C. Piris, The Lisbon Treaty: A Legal and Political Analysis, Cambridge University Press, Cambridge 2010; J.-C. Piris, The Future of Europe-Towards a Two-speed EU, Cambridge University Press, Cambridge 2012; CEPS et al., The Treaty of Lisbon: A Second Look at the Institutional Innovations, Brussels 2010. 
lenges are especially worth noting: the loss of trust in political elites; negative reactions to "external" interference; and the widening "democratic gap" between the EU and its citizens.

\section{Democracy challenge 1: loss of trust in political elites}

The EU's democratic legitimacy suffers from the circumstance that citizens have lost trust in the ability of national and European policy makers to manage and eventually overcome the crisis. A large majority of people feels that political elites have not been able to discipline and tame powerful financial markets.

The declining trust towards political elites is no EU-specific problem but a widespread phenomenon inside and outside Europe. But the mounting loss of confidence in national and European policy-makers has particularly drastic consequences for the European Union, which is to a large extent perceived as elitist project. In other words: growing distrust towards political elites leads to growing distrust towards the elitist European project. This is particularly harmful for the EU, which enjoys a much smaller benefit of the doubt than nation-states and is called into question more quickly and more fundamentally than its constituent members.

\section{Democracy challenge 2: negative reactions to "external" interference}

The crisis and the manifold reactions to it constitute a challenge for national democratic orders as the room for manoeuvre of governments and parliaments becomes more limited, while the socio-economic situation in many EU member states deteriorates. The enhancement of economic governance has led to a higher level of economic and fiscal coordination among EU countries, especially in the euro area, which restricts the latitude of member states. With respect to the programme countries the room of manoeuvre of EU countries such as Greece, Ireland and Portugal has been vastly limited through the detailed and strict conditions attached to the 'bail outs' programmes.

Over the course of the crisis one could already witness manifold negative reactions to the enhanced role of "external actors". The legitimacy of the Commission and its budgetary recommendations have been openly questioned by commentators and even members of national governments..$^{14}$ In the pro-

14. The most impressive example relates to Belgium where in January 2012 a member of government publicly criticised the European Comm ission's new powers in budgetary oversight. 
gramme countries, policy prescriptions agreed with the Troika are (widely) perceived as (negative) external interference. Others again, especially national and European parliamentarians, have criticized the strengthening of intergovernmental cooperation arguing that institutional developments (including the strengthening of the European Council and the establishment of Euro Summits) ${ }^{15}$ and key elements of the crisis recipe (including the Euro Plus Pact or the Fiscal Treaty) have enhanced the role of the executive while undermining the rights of parliaments both at the European and national level.

Criticism of this kind has increased as the crisis progressed and deepened. As member states were not able to contain the crisis neither on the national nor the European level, and as the economic situation in individual countries worsened, large parts of the public have become increasingly critical about the crisis recipe and less ready to accept "interference" blaming the outside for their misery. And the circumstance that national policy-makers abuse the EU as a scapegoat, which is blamed for failures, whereas successes are booked as national accomplishments, has worsened this effect.

\section{Democracy challenge 3: widening "democratic gap"}

The crisis has further intensified the perception among citizens that the Union is a distant apolitical bureaucratic apparatus. The view that citizens are unable to influence the Union's decision-making process is not new, but it has increased in the context of the crisis, as member states are more affected by decisions taken in "Brussels" or "Strasbourg". Trust in the four main EU institutions (EP, European Commission, Council and ECB) has followed a downward trend since autumn 2009. ${ }^{16}$

As a consequence, the EU is increasingly perceived as an "alienated machinery", where citizens are the objects and not the sovereign subjects of European policy-making. This perception springs above all from the fact that the princi-

In an interview with a Belgian daily Minister Paul Magnette said: "The commission is today going too far with its measures. Who knows [economic affairs commissioner] Olli Rehn? Who knows where he has come from and what he has done? Nobody. Yet he tells us how we should conduct economic policy. Europe has no democratic legitimacy to do that". See H. Mahony, "Brussels' new budget powers draw first rebuke", euobserver, 12 January 2012.

15. Euro Summits, which were formalised in October 2011, are meetings bringing together the heads of state or government of the euro countries.

16. See Standard Eurobarometer 75/Spring 2011, Public opinion in the European Union, August 2011, p. 21. 
ple of opposition, the dialectics of political discourse, and the personalization of conflicts play a minimal role in the EU's political system. European political life is still by and large oriented towards consensus and lacks the lifeblood of a thriving democracy, which lives from the clash of colliding arguments as the essence of politics.

The fact that the Lisbon Treaty has substantially strengthened the powers of the European Parliament has not effectively countered the EU's "democratic deficit". ${ }^{17}$ The EP has since the entry into force of the Treaty in December 2009 flexed its new muscles. In a display of power, MEPs initially rejected the SWIFT agreement with the US; pressed the member states for a greater say concerning the European External Action Service (EEAS); effectively compelled the Barroso II Commission to enhance the Parliament's powers in the framework of an inter-institutional agreement; and 'forced' member states to accept a higher level of automaticity in the framework of the reformed Stability and Growth Pact.

No doubt, the Lisbon Treaty has strengthened the EP's role in EU policymaking. But will the Parliament's stronger position bridge the gap between the Union and its citizens? Given that it is the only EU institution with a direct popular mandate, more parliamentary authority should -in theorystrengthen democratic accountability. Such arguments sound appealing. However, they have so far failed the reality test. ${ }^{18}$ The logic of expanding the EP' powers to "democratise" the Union inspired all major rounds of treaty revision since the Single European Act (1987). Yet the strengthening of the European Parliament has only been matched by falling rates in citizen participation -voter turnout at European elections alone steadily dropped from $62 \%$ in 1979 to $43 \%$ in 2009 .

Some have argued that only a higher degree of politicization would be able to effectively bridge the democracy deficit through for example a "dramatization" of European election campaigns, a stronger personalization of European leadership structures and/or a Europeanization of national political debates about EU affairs. ${ }^{19}$

17. See J.-C. Piris, The Future of Europe-Towards a Two-speed EU, op. cit.

18. J.A. Emmanouilidis - C. Stratulat, "Implementing Lisbon: narrowing the EU's 'democratic deficit'?", EPC Policy Brief, Brussels, March 2010.

19. S. Bartolini, "Should the Union be 'Politicised'? Prospects and Risks" in Politics: The Right or the Wrong Sort of Medicine for the EU?, Notre Europe Policy Paper No 19, 2006, pp. 28-49; S. Hix, "Why the EU needs (Left-Right) Politics? Policy Reform and Accountability 
But is the EU ready to move to a higher level of politicization? There are indications that this is not the case. As European integration has reached a high threshold, national political elites seem increasingly less supportive to a higher degree of politicization as they fear the potential consequences of a "loss" of political sovereignty, which would further limit national prerogatives in the last remaining bastions of state sovereignty.

In the course of the last 50 years $\mathrm{EU}$ countries have transferred a large portion of their national powers to "Brussels". A further pooling of sovereignty in areas such as social policy, labour policy, fiscal policy or tax policy would not only reduce the remaining powers of member states, but also deprive national elites of their residual privileges. This is a key reason why national actors -governments, parliaments, parties and even constitutional courts- resist a further strengthening of the EU level in order to avoid their own "power castration".

\section{(iii) A new balance of power and the new German question}

The euro debt crisis has altered the balance of power inside the European Union as Germany has become the leading player. This shift of power poses a challenge to both Berlin and to Germany's partners inside the EU.

Germany's role within the EU started to change already since the mid1990s. The general feeling of belonging to the European Union was never put into question. But during the last two decades, Berlin's European orientation has gradually become more pragmatic, less visionary and determined more by its immediate national economic, political and financial interests. ${ }^{20}$

This development is part of a more fundamental and long-term adaptation

are impossible without it" in Politics: The Right or the Wrong Sort of Medicine for the EU?, op. cit., pp. 1-27; B. Thalmaier, "Partizipation und Politisierung als Antwort auf die Akzeptanzund Legitimationskrise der Europäischen Union", $C^{*} A^{\bullet} P$ Analyse, Munich, March 2006; L. Tsoukalis, "Long on policies but short on politics, the EU needs a breath of fresh air", Europe's World, Spring 2007, pp. 86-91.

20. See, for example, G. Hellmann, "Deutschland in Europa: eine symbiotische Beziehung", Aus Politik und Zeitgeschichte, B-48, 2002, pp. 24-31; J.A. Emmanouilidis, "Deutschland in der EU" in W. Weidenfeld - W. Wessels (eds.), Europa von A bis Z: Taschenbuch der europäischen Integration, Nomos Verlagsgesellschaft, Baden-Baden 2009, pp. 108-114; M. Bauer - J.A. Emmanouilidis, "Deutschland in der EU" in W. Weidenfeld - W. Wessels (eds.), Europa von A-Z: Taschenbuch der europäischen Integration (12th edition), Nomos Verlagsgesellschaft, Baden-Baden 2011, pp. 106-112. 
process following re-unification, which has led to a "normalisation" of Germany's Europapolitik, which is no longer characterized by undisputed political and public support ("permissive consensus") for European integration. ${ }^{21}$ Twenty years down the road, Germany is still adapting to the transition from the Bonn to the Berlin Republic and the pre-Maastricht to the new Lisbon era, the consequences of the failed constitutional project, which created a great deal of disillusion about the future of the European project, and the major enlargement rounds in 2004/2007. With increasing budgetary constraints, especially due to the costs of reunification, the German federal government and the German Länder have also become more and more focused on the financial impacts of EU policies.

The experience of the sovereign debt crisis has fostered the process of "normalisation" and Berlin's more critical and hesitant European orientation became very apparent in early 2010, when the ruling coalition government (CDU/CSU-FDP) led by Chancellor Merkel hesitated to set up a European rescue mechanism to financially support Greece and other peripheral Eurozone countries. While the argument of "solidarity" was still effectively employed in the 1990s to convince Germans of the historical obligation to support "bigbang enlargement", it has become much more difficult for the current Merkel government to make the case for solidarity in the framework of the sovereign debt crisis.

For many decades, European integration was treated as a "sacred cow" in the German political debate. The EU was considered not as a matter of party politics. Germany's pro-European orientation was based on a solid consensus across party lines and critical voices were not welcomed but rather isolated in the political arena. Today, while none of the six parties represented in the German Bundestag can be qualified as "anti-EU", criticism towards the European Union is put forward in all parties both towards issues related to the future overall direction of the $\mathrm{EU}$ and to its day-to-day business.

With respect to the debt crisis, growing segments in the population -pushed by influential parts of the media- feel that Germany has to "pay" for Europe and for a crisis caused by other member states mainly in the EU's southern periphery. As a consequence, the federal government had to cope with

21. See U. Guérot - M. Leonard, "The new German question: How Europe can get the Germany it needs", ECFR Policy Brief, Berlin, April 2011; A. Möller - J.A. Emmanouilidis, "General perception of EU integration: accommodating a "New Germany" in Where is Germany heading?, study directed by R. Dehousse \& E. Fabry, Paris 2010, pp. 3-11. 
growing domestic pressures expecting the executive to "defend" Germany's national interests and Chancellor Merkel has been struggling to organise support within her own party and in the coalition government as well as in the Bundestag and in the Bundesrat, although the two main opposition parties -the social democrats (SPD) and the greens (Bündnis '90/Die Grünen)- have supported (most) major decisions related to solving the sovereign debt crisis.

The political discourse and public debates in Germany started to gradually change in 2011 as the crisis was (strongly) affecting a growing number of EU countries also in the core of the Eurozone (including especially Spain and Italy but also Austria or France). From July/August 2011 onwards one could witness a more differentiated public discourse, as the original crisis recipe focusing predominantly on fiscal austerity -a recipe strongly advocated by the Merkel government- was increasingly challenged not only outside but also inside Germany. However, it remains to be seen whether and to what degree the coalition government will be ready to adapt its position due to increased outside pressure and due to the circumstance that fiscal discipline alone does not seem sufficient to exit the crisis.

With respect to Germany's EU partners, Berlin's handling of the crisis has raised many questions in other capitals and the Merkel government has lost a great deal of sympathy and support across Europe. The German administration was unable to effectively explain its position and convey its policy choices to its partners. But the problem was not "only" bad communication. The underlying problem was more substantial: it is the result of different readings concerning the key reasons for the crisis and different policy preferences concerning crisis management.

Contradictory and often irreconcilable perceptions opposed each other. The Merkel government, representatives of the Bundesbank, and a vast majority of German opinion-makers held that by insisting on the need to cut down public expenditures and to promote fundamental structural reforms at national level they were the ones actually defending European interests and the stability of the common currency. ${ }^{22}$ This assessment contrasted with the position in other $\mathrm{EU}$ countries, especially in those most affected by the euro debt crisis, that Germany's initial reluctance to assist fellow euro countries had played in the hands of speculators and that the heavy focus on austerity had

22. For an analysis, see S. Dullien - U. Guérot, "The long shadow of ordoliberalism: Germany's approach to the euro crisis”, ECFR Policy Brief 49, Berlin, February 2012. 
trapped the EU and especially the countries in Europe's periphery in a negative spiral of low growth, decreasing consumption, rising taxes and increasing ( $y$ outh) unemployment. Germany's economic position, on the other hand, has been substantially strengthened as its economy has weathered the global crisis and the euro debt crisis reasonably well compared to many other member states. After a heavy blow in 2009, the German export-oriented economy recovered rapidly in 2010 and 2011 with growth figures above 3\% accompanied by a substantial decrease in unemployment rates. Less than a decade after Germany was dubbed the 'sick man of Europe', the continent's largest economy has (once again) become Europe's benchmark. The spread differential between German and other European sovereign bonds has become a key indicator of financial (in)stability.

The "normalisation" of Germany's Europapolitik and the shifting economic and political balance of power in the Union bears three major consequences for the EU:

- First, Germany has neglected and lost its traditional role as a mediator between larger and smaller EU countries, actively reaching out in both directions to bring about a critical mass. Berlin is no longer perceived as a motor of supranational integration and as a defender of genuine European interests taking into account also the interests of smaller EU members. On the contrary, Germany is increasingly perceived as an "EU hegemon", who is imposing its will on other EU member states.

- Second, Berlin's strengthened self-confidence has disrupted the old balance between France and Germany, which up till the Kohl-era was characterised by a display of modesty on the part of Germany vis-à-vis the grande nation. Berlin was clearly leading the way and Paris has been struggling to keep pace as France has been struggling to counter the negative economic and financial effects of the crisis.

- Third, the increased pressures on France and the circumstance that Germany has lost its mediating role have negatively affected the leadership role of the Franco-German engine, which has lost trust, credibility, and to a certain degree also attractiveness. At the same, one cannot identify any new, alternative leadership coalition. The presumption that the "big three", including Germany, France and the UK, or the "Weimar Triangle", including Germany, France and Poland could replace the old Franco-German tandem did not materialize. As a result, the EU suffers from a lack of effective and balanced leadership on the level of member states. 
To sum up: Germany is struggling to determine its new role in Europe ${ }^{23}$ and at the same time Berlin's EU partners are in the face of the crisis trying to figure out how to accommodate and react to this "new Germany". In this context, it was somewhat paradoxical to observe complaints about the lack of German leadership in the early phase of the sovereign debt crisis and, subsequently, increasing unease about the growing German dominance after April/ May 2010 when Berlin took the lead and came forward with specific proposals on how to manage the crisis and reform European economic governance.

It is not clear whether the disillusionment of recent years will in the long run increase German scepticism towards (further) European integration. In any case, Berlin and its EU partners will have to accustom and accommodate themselves to this "new Germany". And there is one thing one can learn from the past: the deepening of European integration and the continued pooling of sovereignty have always been a successful way to answer the question of leadership in Europe. ${ }^{24}$

\section{(iv) Global political and economic marginalisation}

The sovereign debt crisis has accelerated the process of Europe's marginalisation on the international scene while global affairs are in a major state of flux. Those who predicted the "end of history" 25 were proven wrong. On the contrary: history is very much in the making -even if we as spectators from the inside at times do not seem to grasp the complexity and speed of developments as well as the gravity of change. The world is in the midst of a major transformative moment and the European Union and its members are under pressure to respond to the fundamental changes and challenges "out there".

It is uncertain how the future global order will look like in the end. ${ }^{26}$ One

23. See J. Janning, “Europe: Germany's dilemma”, EPC Policy Brief, Brussels, December 2011.

24. See A. Möller - J.A. Emmanouilidis, "General perception of EU integration: accommodating a 'New Germany', op.cit., p. 11.

25. See F. Fukuyama, "The End of History", The National Interest, 16, Summer 1989, pp. 3-18; F. Fukuyama, The End of History and the Last Man, Free Press, New York 1992.

26. See also S.G. Brooks - W.C. Wohlforth, World Out of Balance: International Relations and the Challenge of American Primacy, Princeton University Press, Princeton 2008; C.F. Bergsten, "A Partnership of Equals. How Washington Should Respond to China's Economic Challenge", Foreign Affairs, vol. 87, no. 4, July/August 2008, pp. 57-69; R.N. Haass, "The Age of Non-Polarity: What Will Follow US Dominance", Foreign Affairs, vol. 87, no. 3 May/ 
cannot predict which powers will prevail and whether the new system will be characterized by confrontational rivalry or cooperative interdependence between future major players. At any rate, it seems rather certain that countries such as China, India, Brazil and Russia, but also South Africa, Mexico, Indonesia, and/or Turkey will (in most cases) continue to increase their economic, political, cultural, and/or ideological significance and influence. China and India have already emerged as economic and political heavyweights. China holds over a trillion US dollars in hard currency reserves, India's hightech sector is growing by leaps and bounds, both countries are investing in education and infrastructure and constantly increasing their share of the world economy, and both China and India are nuclear powers, who are in the process of developing blue-water navies.

As a consequence of the relative decline of the United States and the "old West" due to the emergence of new powers one can already witness a shift towards a less transatlantic and less Eurocentric world. The US has already turned much more attention to Asia, with a particular focus on the relationship between Washington and Beijing as both the level of economic ("Chimerica") $)^{27}$ and political ("G-2") ${ }^{28}$ interdependence but also the potentials for rivalry between both countries increase.

In the new global order, Europe is no longer in the centre of gravity of international affairs and history, as international developments are more and more shaped in other parts of the world. This geopolitical shift increases the pressure on European to fill the gaps and to rise to the challenges of both regional and global affairs. As Washington loses power and as the US is increasingly shifting its attention to other regions and strategic partners, Europeans will be less and less able to "hide" behind the benevolent hegemon, as they have conveniently done in the past. ${ }^{29} \mathrm{At}$ the same time, Europeans will be increasingly asked by the US and other NATO partners to increase their share in

June 2008, pp. 44-56; G. Grevi, "The Interpolar World: a new scenario", EU-ISS Occasional Paper 79, Paris 2009.

27. N. Ferguason, The Ascent of Money: A Financial History of the World, Penguin Press, New York 2008.

28. Z. Brzezinski, "The Group of Two that could change the world", Financial Times, 13 January 2009.

29. See J. Howorth, "Why the EU Needs a Grand Strategy" in L. Tsoukalis - J.A. Emmanouilidis (eds.), The Delphic Oracle on Europe-Is there a Future for the European Union?, op. cit., pp. 149-164. 
transatlantic burden sharing, since the US will be less and less able and inclined to cope with crises around the globe on its own. At the end of the day, the Americans have an interest in a strong "post-American Europe", able to contribute to the management of world affairs. ${ }^{30}$ However, if Europeans fail to respond to Washington's calls, one can expect that the US will to a lesser extent value the strategic importance and uniqueness of the transatlantic relationship.

In the midst of this major transformative moment it is still unclear which role the "old continent" will play in the twenty-first century. Will Europeans be able to live up to old and new global risks and regional challenges? How influential will the EU and it members be under the conditions of a new global order?

Today -as in 1945 and 1989- Europe finds itself again at a crossroads and things can move in two very opposite directions: Europe could either co-determine the future rules of global governance or rather face decline, gradual marginalization and in the worst case even global irrelevance. ${ }^{31}$

Taken together as an entity the Union and its members would on paper have the economic, political and foreign policy capacities to (continue to) have a decisive impact. ${ }^{32}$ But in order to play a major part in the future management of global affairs, EU countries need to bring their collective weight to bear. In other words: the old continent's future role in international affairs will be largely determined by the political will and the ability of member states to further intensify and deepen cooperation.

But as the old continent faces the challenges of the euro crisis, the EU suffers from introspection, from a loss of strategic direction and a loss of attractiveness both inside and outside Europe. Confronted with the sovereign debt crisis, "the EU resembles a sedate tanker with a glorious history but without a command bridge providing a clear and proactive idea about its next destination" ${ }^{33}$

The perspective of a potential relative economic decline and political marginalisation affects the future prospects for the European integration. The EC/

30. See J. Shapiro - N. Whitney, Towards a Post-American Europe: A Power Audit of EUUS Relations, European Council on Foreign Relations, London 2009.

31. See also F. Algieri, "A Weakened EU's Prospects for Global Leadership", The Washington Quarterly, Vol. 30, No. 1, Winter 2006-07, p. 114.

32. See J.A. Emmanouilidis, 'Europe's Role in the Twenty-First Century', in T. Renard - S. Biscop (eds.), The European Union and Emerging Powers in the 21st Century- How Europe Can Shape a New Global Order, Ashgate 2012, p. 84-87.

33. Ibid, p. 88. 
EU thrived while Europe's prosperity was constantly increasing and while Europeans found themselves -for good or for bad- in the centre of world history. In the beginning of the new millennium the "old continent" finds itself in a very different situation. Many Europeans are faced with growing insecurity. Zukunftsangst has become a widespread phenomenon in many member states -especially in the economically weaker but also in stronger EU countries. People fear the consequences of Europe's potential economic, social and political decline -compared both to other world regions and to previous generations.

Europe is challenged by new economic players and by the negative effects of the global crisis and especially the European debt crisis. The balance of economic power is shifting and Europe might feel the long-term consequences of the crisis more severely than other areas. ${ }^{34}$ Member states are struggling with low growth rates, high unemployment, and high, in some cases even unsustainable debt levels. European companies face fierce competition in almost every sector of the economy. The technological gap between EU countries and non-European competitors in Asia or Southern America is narrowing. European societies face the socio-economic consequences of an ageing and shrinking population. In sum, the Union's collective economic weight is still high, but it is declining in relative terms compared to other economic powers.

As a consequence, more and more Europeans feel a sense of insecurity and anxiety about their future and the future of coming generations. Citizens fear that the economic situation and living standards in Europe will drop ${ }^{35}$ and that the European social model will be increasingly challenged. In this situation the European Union is not perceived as an effective response to the negative forces of globalization. On the contrary, in the eyes of many citizens the EU is viewed as a catalyst of unfettered globalization. At the same time, a majority of citizens seem to want the Union to become a "protective force" that can counter the negative effects of an increasing level of economic, financial and political interdependence. But up till now, the Union has -at least from the perspective of the wider public- not been able to live up to these expectations.

Under these circumstances, it becomes more difficult to argue that the

34. See P.C. Padoan, "Europe's Growth: A Sceptical View" in L. Tsoukalis - J.A. Emmanouilidis (eds.), The Delphic Oracle on Europe-Is there a Future for the European Union?,op. cit., pp. 61-75.

35. See Standard Eurobarometer 76/Autumn 2011, Public opinion in the European Union, first results, December 2011, p. 13. 
European Union (and its members) will become more prosperous and more secure, if only EU countries would opt in favour of a higher degree of integration. In other words: "more Europe" might not turn the tide and reverse some of the megatrends of our time. And the often-used argument that Europe's situation could be worse, if Europeans are unable or unwilling to deepen cooperation, is defensive and thus not particularly attractive neither for policy-makers nor for citizens.

The perspective of a potential relative decline makes it also more difficult to negotiate a new "grand bargain" among EU countries. The search for compromises beyond the lowest common denominator becomes more difficult in the absence of positive-sum trade-offs from which all (or almost all) EU countries would somehow profit. On the contrary, as the going gets tough a growing number of policy-makers and citizens -especially in those countries able to cope with the crisis and the challenges of a changing international setting better than others- might conclude that the national path looks more promising, and some might even hold that the EU and support for some of the weaker member states are a burden on their way out of the crisis in a world more and more influenced by other very vital and energetic powers.

\section{CONCLUSIONS-WILL THE "IRON LAW" PROVE ITSELF AGAIN?}

No doubt, the history of European integration since the 1950s has been a formidable success story. After the experience of two devastating wars the European project has contributed enormously to prosperity, peace, stability, and security in Europe.

The remarkable success story of the European integration project has witnessed many setbacks and crisis triggered by divisions among members, economic recession or external events/challenges. In the 1950s the integration process started with the failure to establish a European Defence Community and a European Political Community. In the 1970s and 1980s the continent lived through an extended period of eurosclerosis during which the integration process lost dynamism while Europe was battling with the oil crisis, fiscal problems and exchange rate turbulence. In the last 20 years, the EU experienced a number of reform crises starting with the Danish "no" to the Maastricht Treaty (1992), the Irish rejection of the Nice Treaty (2001), the crises surrounding the "no" by the French and the Dutch to the 
Constitutional Treaty in 2005, and the Irish refusal to endorse the Lisbon Treaty in 2008.

But despite this long yet inconclusive list of heavy blows, the EU has always overcome its crises and in most cases emerged even stronger than before. Looking back, European integration seems to follow an "iron law" to grow out of crises. The founding of the European Communities in the 1950s, the Single Market project (Europe '92), the abolition of border controls (Schengen), the establishment of joint policies and institutions in the fields of foreign policy, security and defence, the introduction of the euro, the Constitutional Convention and the entry into force of the Lisbon Treaty in 2009 are visible examples that even though European integration has not been crisis-resistant, it has proven to be crisis-proof.

But will the EU and its members be equally able to "exploit" the current crisis? In an ideal world, the EU -and especially the Eurozone countriesshould "use" the crisis as an opportunity to substantially deepen European integration. ${ }^{36} \mathrm{~A}$ (partial and temporary) collateralization of debt, the creation of a European finance ministry, the harmonization of policies such as taxation or social policy, a substantial re-orientation and even increase of the EU budget, and a number of politico-institutional reforms (including, for example, the election of an "EU President" heading both the European Council and the European Commission or a permanent President of the Eurogroup)- all of these proposals should be on the EU's wish list as they would lead to the creation of a sui generis economic and political union able not "only" to solve the euro crisis but also to achieve the strategic objective of a "global Europe"37 capable of playing a key role in determining international political and economic developments in a highly dynamic global environment.

But in today's Europe there is rather confusion about the goals and way ahead. Member states -even the most integration "friendly"- do not seem willing and able to jump into the deep and accept the political and economic implications of a union operating under the conditions of "existential interde-

36. See J.A. Emmanouilidis et al., "Stronger after the crisis-Strategic choices for Europe's way ahead", EPC Strategy Paper, June 2011; P. Swieboda, "Europe from Scratch", demosEUROPA-Centre for European Strategy, Warsaw, February 2012.

37. See J.A. Emmanouilidis, "The Leitmotiv of a Global Europe" in L. Tsoukalis - J.A. Emmanouilidis (eds.), The Delphic Oracle on Europe-Is there a Future for the European Union?, op. cit., pp. 181-204; J.A. Emmanouilidis, 'Europe's Role in the Twenty-First Century', op. cit., p. 94. 
pendence". On the contrary, "(ambitious) muddling through"38 is likely to remain the Union's dominant mantra for the foreseeable future, especially given the increasing distrust between national capitals and societies.

At the end of the day, the Union might still be able to manage, contain or even overcome sovereign debt crisis, but the social and political repercussions -which usually come with a certain time lag- are just as great a concern for the future of the European project. An increasing national focus, simplistic anti-EU populism, the increasing "democratic gap" at both the national and European level, a poisoned atmosphere among EU countries and even between national societies, a lack of leadership coalitions, and the fear of "power castration" at national level could lead to a standstill or even challenge past accomplishments of European integration such as the euro or Schengen.

On the other hand, EU member states have since 2009/2010 proven their (reactive) ability to provide policy responses to the sovereign debt crisis. Much has been accomplished since the outbreak of the crisis, when the EU and its members had no effective means and instruments at their disposal to deal with the crisis. The EU has set up rescue mechanisms and is putting in place an enhanced model of economic governance. Each element of the comprehensive reform package can be challenged. However, taken together the innovations brought forward since 2010 constitute a major leap, which seemed impossible before the outbreak of the crisis.

However, the crisis is far from over. And if the EU and its members want to once again prove the "iron law" of European integration, they will have to make long-term strategic choices with increasing costs if decisions are delayed. Adopting a reactive and defensive approach aimed at "papering over the cracks" will not suffice.

38. See J.A. Emmanouilidis, "The prospects of ambitious muddling through-the results of an EU Summit in deep crisis mode", EPC Post-summit Analysis, July 2012, pp. 12-14. 